\title{
EFFECTIVENESS OF Zr(IV)-LOADED BANANA PEELS BIOMASS FOR THE UPTAKE OF FLUORIDE ANION FROM WATER
}

\author{
Ram Lochan Aryal ${ }^{1,2}$, Bhoj Raj Poudel ${ }^{1}$, Megh Raj Pokhrel ${ }^{1}$, Hari Paudyal ${ }^{1, *}$, Kedar Nath Ghimire $^{1}$ \\ ${ }^{1}$ Central Department of Chemistry, Tribhuvan University, Kirtipur, Kathmandu, Nepal \\ ${ }^{2}$ Department of Chemistry, Amrit Campus, Tribhuvan University, Kathmandu, Nepal \\ *Corresponding author: hpaudyal@cdctu.edu.np \\ (Received: August 02, 2021; Revised: December 7, 2021; Accepted: December 12, 2021)
}

\begin{abstract}
The present study reports the fluoride uptake potential of $\mathrm{Zr}(\mathrm{IV})$-loaded saponified banana peels (Zr(IV)-SBP) from water. $\mathrm{Zr}(\mathrm{IV})-\mathrm{SBP}$ was synthesized by loading $\mathrm{Zr}(\mathrm{IV})$ onto banana peel biomass after saponification and sorbent characterization was performed by using different techniques including FE-SEM (Field Emission Scanning Electron Microscopy), FTIR (Fourier Transform Infra-Red) spectroscopy and zeta potential analysis. Batch experiments were carried out to examine the monitoring factors for the uptake of fluoride onto the investigated adsorbent. The optimal $\mathrm{pH}$ and contact time were found to be 2.94 and 300 minutes, respectively. The results from characterization techniques concurred that $\mathrm{Zr}(\mathrm{IV})-\mathrm{SBP}$ have prominent adsorption sites favorable for the sorption of fluoride ions. The sorption behavior of fluoride onto $\mathrm{Zr}(\mathrm{IV})$-SBP was best fitted with the Langmuir adsorption isotherm and pseudo-second-order kinetics model. The maximum adsorption capacity of $\mathrm{Zr}(\mathrm{IV})-\mathrm{SBP}$ was $36.02 \mathrm{mg} / \mathrm{g}$ using the Langmuir isotherm model. The coexisting ions like chloride and nitrate caused very small interference, elevated concentration of sulphate notably lowers the fluoride adsorption percentage in the binary system, and the sorption using multiple systems was lowered significantly which is due to the synergistic effect of co-existing interfering ion. The adsorbed fluoride was completely desorbed using $2 \mathrm{M} \mathrm{NaOH}$ solution. Fluoride sorption performance of $\mathrm{Zr}(\mathrm{IV})$-SBP demonstrated that it can be a low cost, environmentally benign and one of the highly potent alternatives for the remediation of fluoride ions to avoid ablation on the water.
\end{abstract}

Keywords: Batch experiments, co-existing ions, desorption, fluoride adsorption, Zr(IV)-SBP

\section{INTRODUCTION}

Water is one of the foremost requirements of life in nature. The quality of potable water is degrading day by day around the globe due to natural and anthropogenic activities. The weathering of fluoride-containing rocks and soils, use of fluoride-containing pesticides and disposal of industrial waste into the water resources potentially exacerbate the water quality, which needs proper treatment before use (Aryal et al., 2019; Tan et al., 2020). Fluoride is an integral micronutrient, essential for the human body in trace concentration to maintain healthy bones and teeth but the elevated intake of fluoride caused negative health issues like dental and skeletal fluorosis, neurological disorders, thyroid gland injury and decreased birth rates (Paudyal et al., 2012). Therefore, it is mandatory to lower down the concentration of fluoride anion in drinking water as prescribed by the World Health Organization (WHO, 2016) at the acceptable level of 1.5 $\mathrm{mg} / \mathrm{L}$. In the prior studies, different technologies such as precipitation (Solanki et al., 2021), ion exchange (Grzegorzek et al., 2020), reverse osmosis, nanofiltration (Owusu-Agyeman et al., 2019), and electrodialysis(Djouadi Belkada et al., 2018) have been practiced for the elimination of fluoride ion from polluted water. The lime precipitation cannot lower the fluoride level below $8 \mathrm{mg} / \mathrm{L}$ due to the solubility limit of $\mathrm{CaF}_{2}$ which needs further treatment to meet the legal standard. The commercially available ion exchange resin can selectively remove fluoride ion to less than $1.5 \mathrm{mg} / \mathrm{L}$, but they are expensive for water treatment, whereas other techniques such as reverse osmosis, nano-filtration, electro-dialysis, and membrane separation are amid because of their high operating cost and technically skilled manpower.

Moreover, adsorption is an innovative and low-cost water purification technique thus widely employed to remove fluoride anion from water (Tang et al., 2009). Thus, the adsorption method would be appropriate to eliminate fluoride ion at trace level utilizing selective binding functionalities and reusability of adsorbent without producing secondary pollutants. Many research studies have been initiated in the removal of fluoride using different adsorbents such as orange waste (Paudyal et al., 2011), Citrus limetta (Siddique et al., 2020), oak shell Takmil et al., 2020), modified ceria nanoparticles (Zirpe et al., 2020), Citrus limonum leaf (Tomar et al., 2014), Ulva japonica (Paudyal et al., 2013), Shorea robusta flower petal (Biswas et al., 2017), rick husk biochar (Goswami \& Kumar, 2018), potato peel and rice husk (Bibi et al., 2017), starch with common metals (Xu et al., 2017) and Al-Humic acidLa(III)- aerogels composite (Liu et al., 2016). In contrast, banana fruit is widely cultivated or imported in a country like ours. Banana peel is cellulosic biomass that can be modified to escalate the binding functional sites 
appropriate for fluoride anion adsorption. The literature showed very few research carried out on the banana peels via acid-base treatment for chemical modification (Abdulfatai et al., 2013; Oyewo et al., 2018). However, the adsorption capacity of the adsorbent after chemical treatment is not encouraging. Banana peel contains cellulose (7.6-9.6\%), hemicellulose (6.4-9.4\%), pectin (10$21 \%)$, proteins ( $10.2-12.1 \%)$, and other low molecular weight species (Emaga et al., 2008). The presence of the hydroxyl and methyl ester groups of pectin can be prudent for high adsorption capacity for cations, anions, and organic compounds. The conversion of methyl ester group into carboxyl groups was done by the process of saponification (Ghimire \& Inoue, 2007). In this regard, we speculated that the loading of $\mathrm{Zr}$ (IV) onto saponified banana peels creates favorable adsorption sites which acts as an effective anion exchanger. For this provision, $\mathrm{Zr}(\mathrm{IV})$ has been loaded onto saponified banana peel and employed as adsorbent for fluoride ion removal.

Furthermore, the current research is carried out to explore the potentiality of $\mathrm{Zr}(\mathrm{IV})$-SBP for the uptake of fluoride ion from water. For this purpose, the consequences of different factors like $\mathrm{pH}$, equilibrium time, adsorbent dose, and fluoride ion concentration were analyzed. Adsorption isotherms, kinetic behaviors, and interference of co-existing ions on fluoride adsorption were also examined.

\section{MATERIALS AND METHODS} Chemicals

Zirconium oxychloride octahydrate $\left(\mathrm{ZrOCl}_{2} .8 \mathrm{H}_{2} \mathrm{O}\right)$, sodium fluoride $(\mathrm{NaF})$, calcium hydroxide $\left(\mathrm{Ca}(\mathrm{OH})_{2}\right)$, glacial acetic acid $\left(\mathrm{CH}_{3} \mathrm{COOH}\right)$, sulphuric acid $\left(\mathrm{H}_{2} \mathrm{SO}_{4}\right)$, 1,2 cyclohexylene diamine tetraacetic acid (CDTA) were of analytical grade and purchased from Sigma-Aldrich, New Delhi, India. Sodium hydroxide $(\mathrm{NaOH})$, hydrochloric acid $(\mathrm{HCl})$ as well as salts such as sodium chloride $(\mathrm{NaCl})$, sodium sulphate $\left(\mathrm{Na}_{2} \mathrm{SO}_{4}\right)$, and potassium nitrate $\left(\mathrm{KNO}_{3}\right)$ were procured from Thermo Fisher Scientific Pvt. Ltd., India. All working solutions were prepared in double-distilled water (conductivity = 18.2 MS.cm; pH = 6.81). The fluoride stock solution $(1000 \mathrm{mg} / \mathrm{L})$ was prepared by dissolving $2.21 \mathrm{~g}$ of $\mathrm{NaF}$ in $1000 \mathrm{~mL}$ water. The working solutions of desired concentrations were prepared by successive dilutions of the corresponding stock solutions throughout the experiments.

\section{Adsorbent preparation}

The banana peels used in this study were collected from the local fruit vending center of Bhotahity, Kathmandu, Nepal. After washing thoroughly with water, it was sundried for ten days and cut into small pieces, and sieved to pass through $150 \mu \mathrm{m}$. The powdered banana peel was washed repeatedly with deionized water to remove soluble unwanted contaminants and was dried in an oven at $343 \mathrm{~K}$ for $24 \mathrm{~h}$. It was named raw banana peel and hereafter, abbreviated as RBP.

About $100 \mathrm{~g}$ of RBP powder was mixed with $500 \mathrm{~mL}$ of a saturated solution of lime water. The $\mathrm{pH}$ of the mixture was adjusted around 12.0 putting a few sodium hydroxides pellets. The mixture was equilibrated at a speed of $190 \mathrm{rpm}$ for $24 \mathrm{~h}$ at a temperature of $293 \mathrm{~K}$ for the completion of the saponification reaction. After equilibration, the suspension was washed frequently with distilled water almost to neutrality and was dried in an oven at $343 \mathrm{~K}$. Thus, obtained material is named as saponified banana peel and abbreviated as SBP hereafter. The loading of $\mathrm{Zr}(\mathrm{IV})$ onto SBP was done by the procedure as follows.

About $3 \mathrm{~g}$ of SBP was treated with $500 \mathrm{~mL}$ of $0.1 \mathrm{M}$ $\mathrm{ZrOCl}_{2} .8 \mathrm{H}_{2} \mathrm{O}$ solution in $0.1 \mathrm{M}$ HEPES buffer $(\mathrm{pH}=$ 2.2). Then, the mixture was equilibrated for $24 \mathrm{~h}$ at a speed of $190 \mathrm{rpm}$. After filtration, the residual product obtained in this way was repeatedly washed with double distilled water until neutral $\mathrm{pH}$ and dried. The dried mass is called $\mathrm{Zr}(\mathrm{IV})$ loaded SBP and abbreviated as $\mathrm{Zr}(\mathrm{IV})$ SBP hereafter.

\section{Characterizations of the adsorbent}

The functional groups' changes occurred during adsorbent preparation and the interaction involved between fluoride and $\mathrm{Zr}(\mathrm{IV})-\mathrm{SBP}$ was determined in the wavenumber range of 4000 to $400 \mathrm{~cm}^{-1}$ from FTIR spectroscopy using IR Affinity-1S SHIMADZU spectrometer (Kyoto, Japan). SEM images of $\mathrm{Zr}(\mathrm{IV})$-SBP before and after fluoride adsorption were recorded on a JEOL JSM-6700 F (JEOL, Tokyo, Japan) scanning electron microscope. Zeta potential analyzer (HORIBA Scientific SZ-100) was used to investigate the surface charge of the $\mathrm{Zr}(\mathrm{IV})-\mathrm{SBP}$ at different $\mathrm{pH}$. The $\mathrm{pH}$ meter (CHEMI LINE CL-180) was operated for the measurement of the $\mathrm{pH}$ of the fluoride solution. The concentration of fluoride ion in the water samples was examined with the help of a fluoride ion selective electrode (Bante930 precision $\mathrm{pH} /$ Ion meter).

\section{Batch adsorption experiments}

The performance of RBP and $\mathrm{Zr}(\mathrm{IV})$-SBP for fluoride adsorption was investigated in batch equilibration mode at lab temperature $(295 \pm 2 \mathrm{~K})$. Adsorption experiments were accomplished under different $\mathrm{pH}$, adsorbent dose, fluoride concentration and agitation times. The influence of solution $\mathrm{pH}$ was examined by agitating $30 \mathrm{mg}$ of the adsorbent with $20 \mathrm{~mL}$ of fluoride solution $(10 \mathrm{mg} / \mathrm{L})$ at different $\mathrm{pH}$ values (1-12). The solution $\mathrm{pH}$ was regulated by adding a dilute solution of $\mathrm{HCl}$ and $\mathrm{NaOH}(0.1 \mathrm{M}$ each). The suspension was equilibrated for $24 \mathrm{~h}$. The removal efficiency of fluoride ( $\% \mathrm{R})$ and the equilibrium adsorption capacity $\left(\mathrm{q}_{\mathrm{e}}\right)$ were evaluated from the equation (1) and (2) as, 
$(\% \mathrm{R})=\frac{C_{o}-C_{e}}{C_{0}} \times 100$

$\mathrm{q}_{\mathrm{e}}=\frac{\left(C_{0}-C_{e}\right)}{m} \times \mathrm{V}$

where $\mathrm{C}_{0}$ and $\mathrm{C}_{\mathrm{e}}$ refer to the initial and equilibrium concentration of fluoride $(\mathrm{mg} / \mathrm{L})$, respectively, $\mathrm{m}$ is the mass of the adsorbent $(\mathrm{g})$, and $\mathrm{V}$ is the volume of fluoride solution in liter.

The effect of adsorbent dose in the order of $0.1-4 \mathrm{~g} / \mathrm{L}$ was studied agitating with $20 \mathrm{~mL}$ of $10 \mathrm{mg} / \mathrm{L}$ of fluoride at optimum $\mathrm{pH}$. Also, $30 \mathrm{mg}$ of adsorbent with varying concentrations of fluoride at a range of $1-300 \mathrm{mg} / \mathrm{L}$ at optimum $\mathrm{pH}$ was investigated for isotherm study. Additionally, the consequences of contact time on fluoride adsorption $(10 \mathrm{mg} / \mathrm{L})$ at optimum $\mathrm{pH}$ were studied in the range of $5-480 \mathrm{~min}$ at a solid-liquid ratio of $1.5 \mathrm{~g} / \mathrm{L}$. All batch adsorption experiments except the kinetic study were agitated for $24 \mathrm{~h}$ at a speed of $190 \mathrm{rpm}$. The effect on fluoride adsorption due to co-existing ions was examined by equilibrating $30 \mathrm{mg}$ of the adsorbent, 10 $\mathrm{mg} / \mathrm{L}$ of fluoride ion, and varying concentration (10-200 $\mathrm{mg} / \mathrm{L}$ ) of co-existing $\mathrm{Cl}^{-}, \mathrm{NO}_{3}^{-}$and $\mathrm{SO}_{4}^{--}$in separate containers. After each adsorption experiment, the suspension was filtered instantly using $42 \mu \mathrm{m}$ Whatman filter paper and the remnant concentration of fluoride ion in the solution was analyzed by fluoride ion-selective electrode. To measure the zeta potential of the adsorbent, the suspension was made by agitating $30 \mathrm{mg}$ of the $\mathrm{Zr}(\mathrm{IV})-\mathrm{SBP}$ with $20 \mathrm{~mL}$ deionized water at varying $\mathrm{pH}$ of 1-12 for $24 \mathrm{~h}$. All the experiments were performed in triplicates and average data are presented in this paper.

\section{Modelling of adsorption isotherm and kinetic data}

Adsorption isotherms are used to presume the correlation between the amount of fluoride adsorbed onto the adsorbent surface and the equilibrium concentration in the solution while kinetic studies direct the fluoride adsorption rate onto the adsorbents. The results obtained were further modeled using Langmuir \&Freundlich isotherms and pseudo-first order \&pseudo-second-order rate equations. The Langmuir adsorption isotherm deals with the monolayer adsorption with the homogeneous surface active sites (Sposito, 1982). Langmuir equation in the linear form is shown in equation (3) as,

$\frac{\mathrm{C}_{\mathrm{e}}}{\mathrm{q}_{\mathrm{e}}}=\frac{1}{\mathrm{q}_{\mathrm{m}} \mathrm{b}}+\frac{\mathrm{C}_{\mathrm{e}}}{\mathrm{q}_{\mathrm{m}}}$

where $C_{e}$ is the equilibrium concentration of fluoride in the solution $(\mathrm{mg} / \mathrm{L}), \mathrm{q}_{\mathrm{e}}$ is the amount of fluoride adsorbed per unit mass of the adsorbent $(\mathrm{mg} / \mathrm{g}), \mathrm{q}_{\mathrm{m}}$ is the maximum adsorption capacity $(\mathrm{mg} / \mathrm{g})$ and $\mathrm{b}$ is the Langmuir adsorption constant related to binding energy $(\mathrm{L} / \mathrm{mg})$. The maximum adsorption capacity $\left(\mathrm{q}_{\max }\right)$ and Langmuir adsorption constant (b) were evaluated from the slope and intercept of the linear plot of $\mathrm{C}_{\mathrm{e}} / \mathrm{q}_{\mathrm{e}}$ versus $\mathrm{C}_{\mathrm{e}}$. To predict whether the adsorption process is favorable or not, the Langmuir isotherm is characterized by the dimensionless separation factor $\left(\mathrm{R}_{\mathrm{L}}\right)$ using equation (4) as,

$\mathrm{R}_{\mathrm{L}}=\frac{1}{1+b \cdot C_{o}}$

For a favorable adsorption process, the value of $\mathrm{R}_{\mathrm{L}}$ lies in the range of $0<\mathrm{R}_{\mathrm{L}}<1$.

Freundlich isotherm deals with the multilayer adsorption with the heterogeneous surface (Appel, 1973). Freundlich equation in the linear form is shown in equation (5),

$\log \mathrm{q}_{\mathrm{e}}=\log \mathrm{K}_{\mathrm{F}}+(1 / \mathrm{n}) \log \mathrm{C}_{\mathrm{e}}$

where $\mathrm{C}_{e}$ is the concentration of fluoride in the solution at equilibrium $(\mathrm{mg} / \mathrm{L}), \mathrm{q}_{\mathrm{e}}$ is the amount of fluoride adsorbed per unit mass of the adsorbent $(\mathrm{mg} / \mathrm{g}), \mathrm{K}_{\mathrm{F}}$ is Freundlich constant related to binding sites $(\mathrm{mg} / \mathrm{g})$ and $1 / \mathrm{n}$ is dimensionless heterogeneity factor. The value of $K_{F}$ and $1 / \mathrm{n}$ was evaluated from the intercept and slope of the plot of $\log \mathrm{qe}_{\mathrm{e}}$ versus $\log \mathrm{C}_{\mathrm{e}}$.

The kinetic studies were carried out to investigate the equilibrium time and validate the adsorption mechanism of fluoride onto the adsorbent. The data were computed in the pseudo first order and pseudo second order models to evaluate the mechanism of adsorption. The pseudo first order and pseudo second order model are expressed in the linear form in the equations (6) and (7) as,

$\log \left(\mathrm{q}_{\mathrm{e}^{-}} \mathrm{q}_{\mathrm{t}}\right)=\log \mathrm{q}_{\mathrm{e}}-\frac{\mathrm{k}_{1}}{2.303} \mathrm{t}$

$\frac{\mathrm{t}}{\mathrm{q}_{\mathrm{t}}}=\frac{1}{\mathrm{k}_{2} \mathrm{q}_{\mathrm{e}}^{2}}+\frac{1}{\mathrm{q}_{\mathrm{e}}} \mathrm{t}$

where $q_{e}$ is the amount of fluoride adsorbed per unit mass of the adsorbent $(\mathrm{mg} / \mathrm{g}), \mathrm{q}_{\mathrm{t}}$ is the amount of fluoride adsorbed per unit mass of the adsorbent $(\mathrm{mg} / \mathrm{g})$ at time $\mathrm{t}$ (min) and $\mathrm{k}_{1}$ and $\mathrm{k}_{2}$ are the pseudo first order and pseudo second order rate constant for the adsorption $\left(\mathrm{min}^{-1}\right)$. From equation (6), the values of $\mathrm{q}_{\mathrm{e}}$ and $\mathrm{k}_{1}$ were computed from the plot of $\log \left(\mathrm{q}_{\mathrm{e}}-\mathrm{q}_{\mathrm{t}}\right)$ versus $\mathrm{t}$. Similarly, from equation (7), the values of $\mathrm{q}_{\mathrm{e}}$ and $\mathrm{k}_{2}$ were determined from the plot $\mathrm{t} / \mathrm{q}_{\mathrm{t}}$ versus $\mathrm{t}$.

\section{Desorption studies}

For desorption studies, the fluoride loaded $\mathrm{Zr}(\mathrm{IV})-\mathrm{SBP}$ was first prepared by equilibrating $1 \mathrm{~g}$ of $\mathrm{Zr}(\mathrm{IV})-\mathrm{SBP}$ with $500 \mathrm{~mL}$ of $120 \mathrm{mg} / \mathrm{L}$ of fluoride solution at an optimum $\mathrm{pH}$ for $24 \mathrm{~h}$. Then, the suspension was filtered, and the filtrate was analyzed for fluoride ion to evaluate adsorption amount of fluoride by $\mathrm{Zr}$ (IV)-SBP while the fluoride loaded residue was oven-dried at $343 \mathrm{~K}$, which is termed as fluoride adsorbed $\mathrm{Zr}(\mathrm{IV})-\mathrm{SBP}$ and termed as F$\mathrm{Zr}(\mathrm{IV})-\mathrm{SBP}$ hereafter. It is used for the desorption experiment. For desorption, $10 \mathrm{~mL}$ of $\mathrm{NaOH}(0.01-3 \mathrm{M})$ and $30 \mathrm{mg}$ of $-\mathrm{F}-\mathrm{Zr}(\mathrm{IV})-\mathrm{SBP}$ were mixed individually in separate containers and stirred for $24 \mathrm{~h}$. After filtration, the filtrate was analyzed to evaluate the desorbed amount of fluoride ion. The desorption efficiency (D \%) of fluoride was estimated using the following equation, 
Desorption efficiency $(\mathrm{D} \%)=\frac{F_{D}}{F_{A}} \times 100$

where, $F_{D}$ and $F_{A}$ are the total amount of fluoride desorbed and adsorbed in $\mathrm{mg} / \mathrm{g}$, respectively.

\section{RESULTS AND DISCUSSION}

\section{Chemical modification of banana peel}

Banana pectin contains methyl ester groups in its polymeric chain including free carboxyl groups. The ester can be modified into a carboxyl group by saponification. The banana pectin is partially methylated thus methyl ester part of banana peel was modified using lime water to convert them into carboxyl group as calcium carboxylate known as saponified banana peel (SBP) as shown in scheme 1 (step 1).SBP has exchangeable calcium which can be exchanged with metal ions so acts as a cation exchanger, but further modification is required to create anion exchange property. The loading of $\mathrm{Zr}(\mathrm{IV})$ ions onto SBP took place by the exchange of $\mathrm{Ca}(\mathrm{II})$ ion through a cation exchange mechanism (Paudyal et al., 2012) as shown in scheme 1 (step 2). It is inferred that the neutralization of all four positive charge of $\mathrm{Zr}(\mathrm{IV})$ by the carboxyl group in SBP is impossible due to steric hindrance caused by the big polymeric structure of banana pectic acid thus one or two positive charges of $\mathrm{Zr}(\mathrm{IV})$ is neutralized using carboxyl group of SBP and rest are neutralized by hydroxyl ions. These hydroxyl ions were expected to be neutralized during fluoride adsorption.

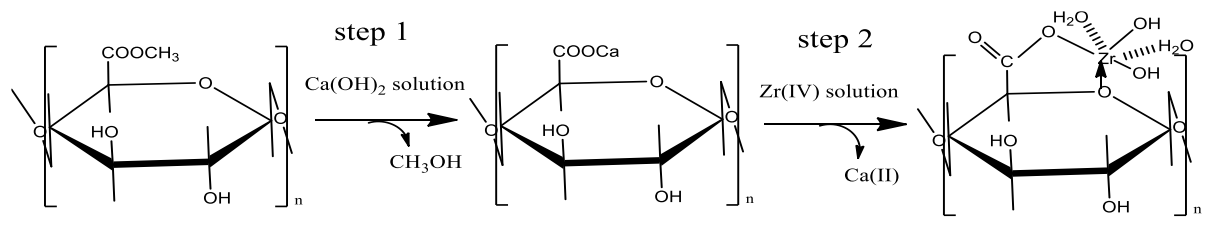

Scheme -1. Synthesis of $\mathrm{Zr}(\mathrm{IV})$ loaded saponified banana peel ( $\mathrm{Zr}(\mathrm{IV})-\mathrm{SBP})$ adsorbent for fluoride ion adsorption

Analysis of functional groups by FTIR spectroscopy FTIR analysis was carried out for the RBP, SBP, and $\mathrm{Zr}(\mathrm{IV})-\mathrm{SBP}$ as shown in Fig. 1. The spectra of RBP show a broad band at around $3340 \mathrm{~cm}^{-1}$ is the stretching vibration of $-\mathrm{OH}$ groups of cellulose, hemicelluloses, pectin, and lignin in banana peel biomass. This peak becomes broad enough in $\mathrm{Zr}$ (IV)-SBP due to absorbed water molecules and coordinated hydroxyl groups. The peak at around $2947 \mathrm{~cm}^{-1}$ is due to $\mathrm{C}-\mathrm{H}$ stretching vibration of an alkyl group. The peak at around $1735 \mathrm{~cm}^{-1}$ is of $\mathrm{C}=\mathrm{O}$ stretching vibration of the carboxyl group in ester. This peak was disappeared after saponification
(SBP) and two new peaks were appeared at around 1640 and $1380 \mathrm{~cm}^{-1}$ which are the characteristic peaks of metal carboxylate (here calcium carboxylate). Likewise, after $\mathrm{Zr}$ (IV) loading, these peaks shift to a lower frequency region at around 1427 and $1150 \mathrm{~cm}^{-1}$ which can be reasonably attributed due to the substitution of calcium ions by the zirconium ions of higher atomic weight (Gawkowska et al., 2019). The results from FTIR spectroscopy manifested that the carboxylic group is the primary functional group that undergoes a chemical modification process during saponification and $\mathrm{Zr}(\mathrm{IV})$ loading.

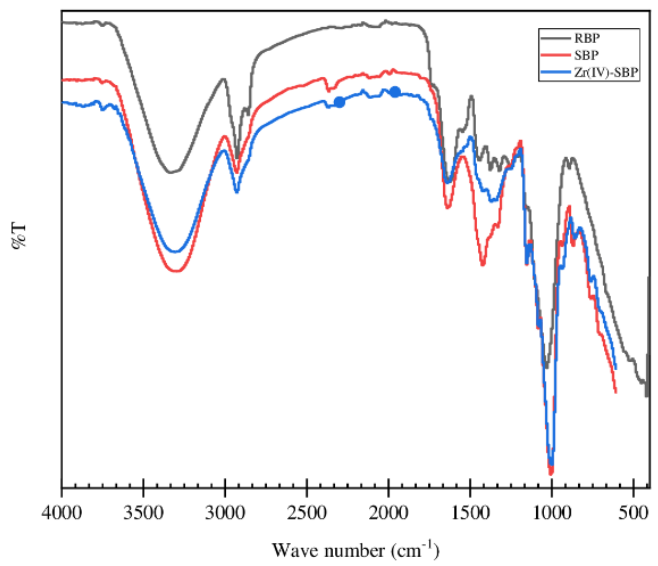

Figure 1. FTIR spectra of RBP, SBP, and $\mathrm{Zr}(\mathrm{IV})$-SBP adsorbent 
Determination of surface morphology and surface charge

SEM images of $\mathrm{Zr}(\mathrm{IV})-\mathrm{SBP}$ prior and after adsorption of fluoride were recorded as depicted in Fig. 2 (a) and (b). The result displayed that the $\mathrm{Zr}(\mathrm{IV})-\mathrm{SBP}$ has a little bit rough, irregular with ups and down on the surface(Fig. 2a) which manifests the appropriate surface morphology for the adsorption reaction. After adsorption, the surface of fluoride laden $\mathrm{Zr}(\mathrm{IV})-\mathrm{SBP}$ becomes smooth and uniform (Fig. 2b) compared to $\mathrm{Zr}(\mathrm{IV}) \mathrm{SBP}$ itself, which is attributed possibly due to the occupancy of fluoride anion onto $\mathrm{Zr}(\mathrm{IV})-\mathrm{SBP}$ surface during the adsorption process. A similar change in surface morphology was observed by Jeyaseelan et al. (2021) in the case of fluoride ion adsorption using amine functionalized iron-based metal organic frameworks.
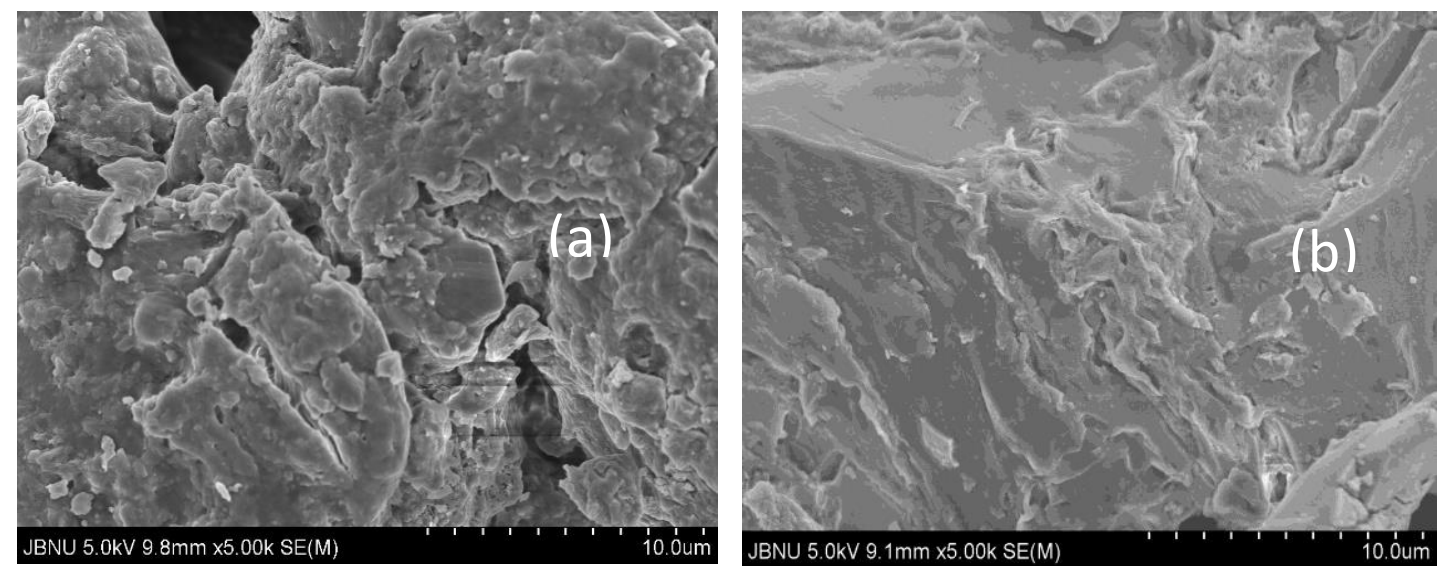

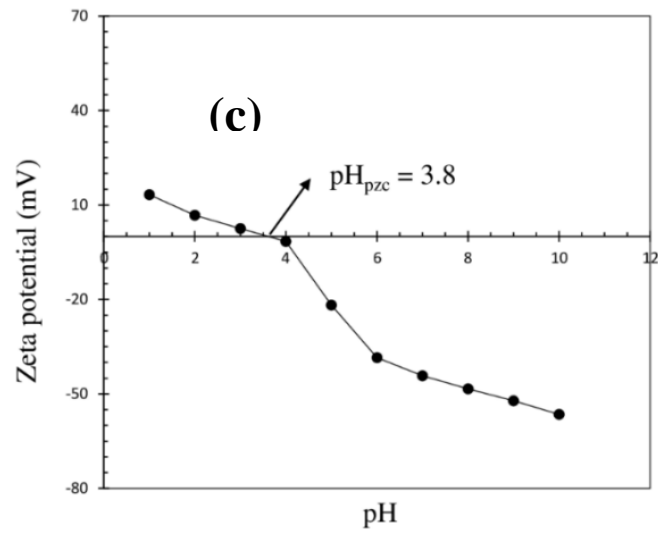

Figure 2. SEM images of (a) $\mathrm{Zr}(\mathrm{IV})-\mathrm{SBP}$, (b) $\mathrm{Zr}$ (IV)-SBP after the adsorption of fluoride and (c) Zeta potential of $\mathrm{Zr}$ (IV)SBP at different $\mathrm{pH}$ showing $\mathrm{pH}_{\mathrm{PZC}}$

The point of zero charges ( $\mathrm{pH}_{\mathrm{pzc}}$ ) of $\mathrm{Zr}(\mathrm{IV})-\mathrm{SBP}$ using zeta potential measurement was found to be around 3.8 as depicted by Fig. 2(c). The surface charge of the adsorbent at this $\mathrm{pH}$ is neutral. Zeta potential values become more negative with increasing $\mathrm{pH}$ of sample solution which inferred that the surface charge of the $\mathrm{Zr}(\mathrm{IV})$-SBP relies on solution $\mathrm{pH}$. At lower $\mathrm{pH}$, the surface charge of $\mathrm{Zr}(\mathrm{IV})-\mathrm{SBP}$ is positively charged which facilitates the adsorption of fluoride by coulombic interaction. The decrease in adsorption of fluoride at $\mathrm{pH}$ below 2.0 is due to undissociated hydrogen fluoride (HF) which is poorly adsorbed onto anion exchange sites of $\mathrm{Zr}(\mathrm{IV})-\mathrm{SBP}$. But, at $\mathrm{pH}$ higher than $\mathrm{pH}_{\mathrm{pzc}}$, the surface of $\mathrm{Zr}(\mathrm{IV})-\mathrm{SBP}$ is negatively charged, eventually, hydroxyl ions compete with fluoride anions for the adsorption sites, as a result, poor adsorption of fluoride takes place.

\section{Effect of solution $\mathrm{pH}$ and mechanism of fluoride} adsorption

The $\mathrm{pH}$ of the solution is one of the controlling parameters for the adsorption of fluoride onto the adsorbent because it changes the surface charge properties of adsorbent and speciation of adsorbate ion. A plot of equilibrium $\mathrm{pH}$ of solution for fluoride ion adsorption onto RBP and $\mathrm{Zr}(\mathrm{IV})-\mathrm{SBP}$ is depicted in Fig. 3. The result shows that the fluoride adsorption onto RBP was insignificant $(<24 \%$ even at optimum $\mathrm{pH})$. However, $\mathrm{Zr}(\mathrm{IV})-\mathrm{SBP}$ shows significant improvement in the removal of fluoride ions and has reached a maximum value $(94.5 \%)$ at $\mathrm{pH}=2.9$, then declined gradually with elevated $\mathrm{pH}$. From the speciation of fluoride in an aqueous medium, the neutral species of fluoride (HF) is dominant at low $\mathrm{pH}$ with a small proportion of hydrogen 
difluoride $\left(\mathrm{HF}_{2}^{-}\right)$anion while greater than $90 \%$ of free fluoride anion $\left(\mathrm{F}^{-}\right)$is dominant at $\mathrm{pH}$ higher than 5 . At $\mathrm{pH}$ $<2$, the $\mathrm{H}^{+}$ions present in solution combined with $\mathrm{F}^{-}$ ions form weakly ionizable hydrofluoric acid (reaction a), due to which $\mathrm{F}^{-}$ions are less available for adsorption, which accounts for low adsorption. The adsorption of fluoride onto $\mathrm{Zr}(\mathrm{IV})-\mathrm{SBP}$ at $\mathrm{pH}$ around 3 is observed to be maximum. At this $\mathrm{pH}$, the coordinated hydroxyl ligand exists in the co-ordination sphere of loaded $\mathrm{Zr}(\mathrm{IV})$ in $\mathrm{Zr}(\mathrm{IV})-\mathrm{SBP}$ is protonated to produce a positively charged surface (reaction b) where the interaction of fluoride anion occurs by coulombic interaction then adsorption of fluoride occurred with the release of water as shown in reaction $\mathbf{c}$. The net reaction occurs by a ligand exchange reaction between fluoride anions and hydroxyl ligands as shown in reaction $\mathbf{d}$. The adsorption of fluoride decreases eventually as $\mathrm{pH}$ increases, which may be attributed due to competition between the elevated amount of hydroxyl ions and fluoride ions.

$$
\begin{aligned}
& \mathrm{H}^{+}+\mathrm{F}^{-} \rightarrow \mathrm{HF} \quad(\mathrm{a}) \\
& \equiv \mathrm{Zr}-\mathrm{OH}+\mathrm{H}^{+} \rightarrow \equiv \mathrm{Zr}-\mathrm{OH}_{2}^{+} \text {(positively charged) } \\
& \equiv \mathrm{Zr}-\mathrm{OH}_{2}{ }^{+}+\mathrm{F}^{-} \rightarrow \rightarrow \mathrm{Zr}-\mathrm{F}+\mathrm{H}_{2} \mathrm{O}
\end{aligned}
$$

Net reaction: $\equiv \mathrm{Zr}-\mathrm{OH}+\mathrm{F}^{-} \rightarrow \equiv \mathrm{Zr}-\mathrm{F}+\mathrm{OH}^{-}$

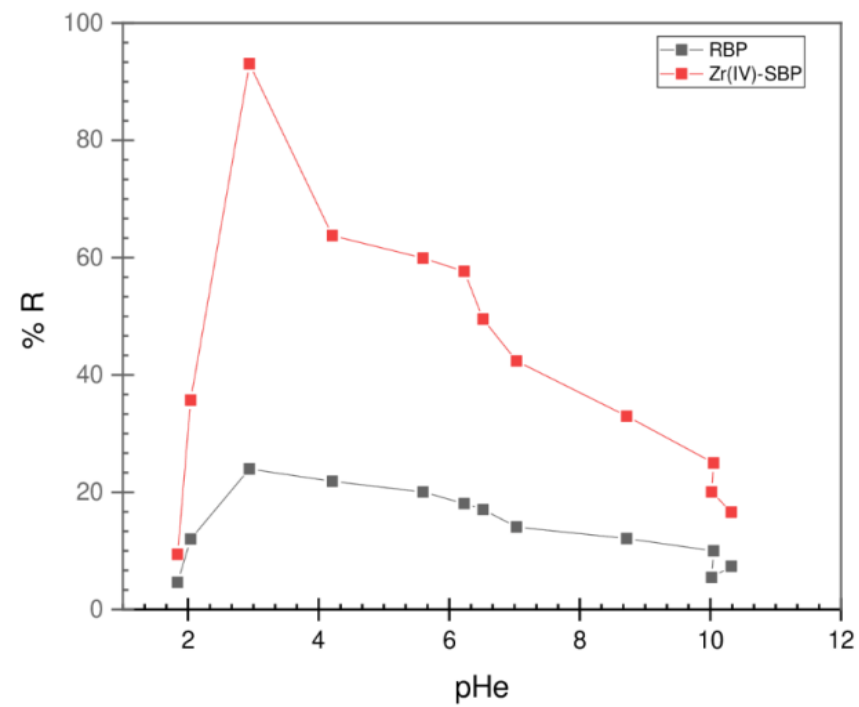

Figure 3. Effect of solution $\mathrm{pH}$ in the fluoride adsorption onto $\mathrm{RBP}$ and $\mathrm{Zr}(\mathrm{IV})-\mathrm{SBP}$ adsorbents

\section{Effect of contact time}

The kinetic studies of fluoride adsorption using $\mathrm{Zr}(\mathrm{IV})$ SBP adsorbent were carried out at optimum $\mathrm{pH}$ of 2.9 and the results obtained are shown in Fig. 4. It is evident from the result of this figure that the adsorption rate of fluoride is observed to be rapid at the beginning and becomes slower and achieved equilibrium within 300 minutes. Higher adsorption rates of fluoride ion at the beginning of the experiment can be attributed due to the existence of a greater number of vacant active adsorption sites. As the contact time increased, most of the vacant sites in $\mathrm{Zr}(\mathrm{IV})$-SBP were occupied by fluoride ion leads to a decrease in the fluoride adsorption rate (Mahfoudhi $\&$ Boufi, 2020). To identify the most reliable adsorption model and the adsorption mechanism, the experimental data were fitted to pseudo-first order and pseudo-second order kinetic models as given in equations (6) and (7), and the graphs are displayed in Figs. 4 (b) and 5 (c). The rate constants and other parameters obtained from the graphs are presented in table 1 . The experimental value of $\mathrm{q}_{\mathrm{e}}$ was found very close $(6.58 \mathrm{mg} / \mathrm{g})$ to the calculated value of $\mathrm{q}_{\mathrm{e}}$ from the pseudo second order plot (6.44 $\mathrm{mg} / \mathrm{g})$ with correlation coefficient value $\left(\mathrm{R}^{2}=0.99\right)$ than pseudo first order model (3.63 $\mathrm{mg} / \mathrm{g}$ ), which suggests that the second order kinetic model fits better to explain the adsorption kinetics of fluoride onto $\mathrm{Zr}(\mathrm{IV})$ SBP.

Table 1. Kinetic parameters for adsorption of fluoride onto $\mathrm{Zr}(\mathrm{IV})$-SBP adsorbent

\begin{tabular}{lll}
\hline Kinetic Models & \multicolumn{1}{c}{ Parameters } & \\
\hline Pseudo first order & $\mathrm{k}_{1}\left(\mathrm{~min}^{-1}\right)$ & 0.02 \\
& $\mathrm{q}_{\mathrm{e}, \text { cal. }}(\mathrm{mg} / \mathrm{g})$ & 3.63 \\
& $\mathrm{R}^{2}$ & 0.94 \\
& & 0.02 \\
Pseudo second order & $\mathrm{k}_{2}(\mathrm{~g} / \mathrm{mg} \mathrm{min})$ & 6.59 \\
& $\mathrm{q}_{\mathrm{e}, \text { cal. }}(\mathrm{mg} / \mathrm{g})$ & 0.99 \\
& $\mathrm{R}^{2}$ & 6.44 \\
\hline
\end{tabular}



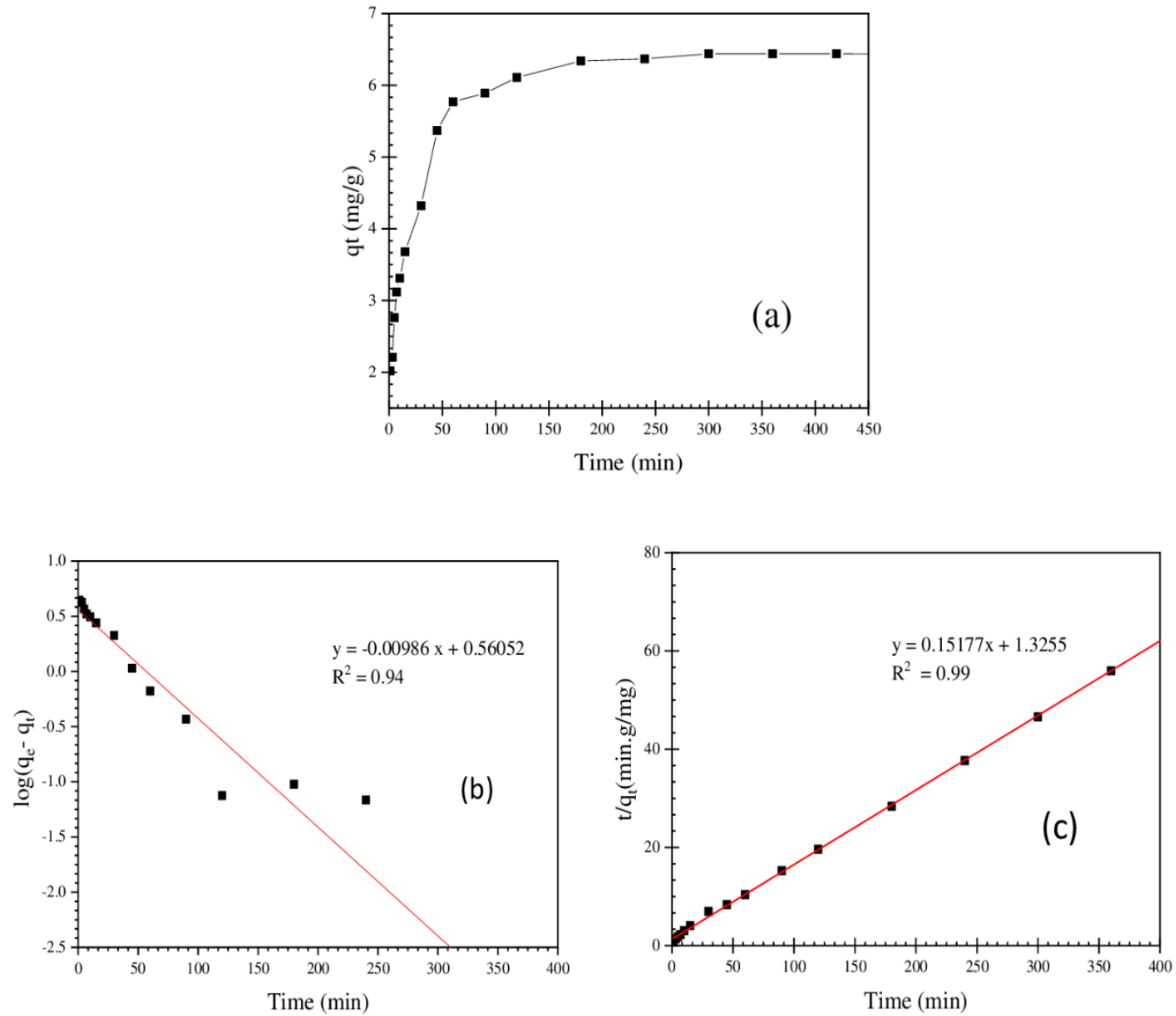

Figure 4. Adsorption of fluoride onto $\mathrm{Zr}(\mathrm{IV})$-SBP (a) Effect of contact time (b) pseudo first order and (c) pseudo second order model

\section{Adsorption isotherm}

The adsorption isotherm represents the relationship between the amount of adsorbate uptake by the investigated adsorbent with the equilibrium concentration of adsorbate remains after the adsorption reaction. Figure 5 shows the adsorption isotherm of fluoride using $\mathrm{Zr}(\mathrm{IV})$ SBP adsorbent. It shows that fluoride uptake capacity of $\mathrm{Zr}$ (IV)-SBP increase at lower concentrations whereas it is found to be level off or attains a plateau value at higher concentrations. To investigate the best fit model, the experimental data were modeled using Langmuir and Freundlich isotherms according to equations (3) and (5) and the plots are presented in Figs. 5(b) and 5(c) and evaluated isotherm parameters are listed in table 2. The results indicated that the data fitted well with the Langmuir isotherm model with a high correlation coefficient $\left(\mathrm{R}^{2}=0.99\right)$ compared to the Freundlich isotherm model $\left(\mathrm{R}^{2}=0.90\right)$. It declares that fluoride adsorption onto $\mathrm{Zr}(\mathrm{IV})-\mathrm{SBP}$ follows according to the Langmuir theory of monolayer adsorption. The obtained results are consistent with the previous studies for fluoride adsorption using zirconium based metal organic framework and La(III) loaded seaweed (Paudyal et al.,
2013; Tan et al., 2020). Therefore, maximum adsorption capacity and adsorption constant of $\mathrm{Zr}(\mathrm{IV})-\mathrm{SBP}$ were evaluated to be $36.02 \mathrm{mg} / \mathrm{g}$ and $0.23 \mathrm{~L} / \mathrm{g}$, respectively, using the Langmuir isotherm model. In addition, the value of the dimensionless parameter, $\mathrm{R}_{\mathrm{L}}$ ranged between 0.01 to 0.8 for the fluoride anion adsorption onto $\mathrm{Zr}(\mathrm{IV})-\mathrm{SBP}$ as in Fig. 5(d), which come up with the favorable adsorption process assigned by $0<\mathrm{R}_{\mathrm{L}}<1$.

The comparison of fluoride uptake capacity of investigated $\mathrm{Zr}(\mathrm{IV})-\mathrm{SBP}$ with the adsorbent reported in the literature is presented in table 3 . It shows that the adsorbent such as Cocos nucifera root, engineered biochar, calcium chloride modified Crocus sativa leaves showed low adsorption potential for fluoride whereas the adsorption performance using metal loaded adsorbents is higher. The fluoride uptake capacity of $\mathrm{Zr}(\mathrm{IV})$-SBP investigated in this study is satisfactory. Moreover, it is low cost because the feed material for the synthesis of $\mathrm{Zr}(\mathrm{IV})-\mathrm{SBP}$ is waste banana peel itself. Thus, it is expected that the $\mathrm{Zr}(\mathrm{IV})-\mathrm{SBP}$ can be employed as a potential alternative for the treatment of fluoride polluted water. 

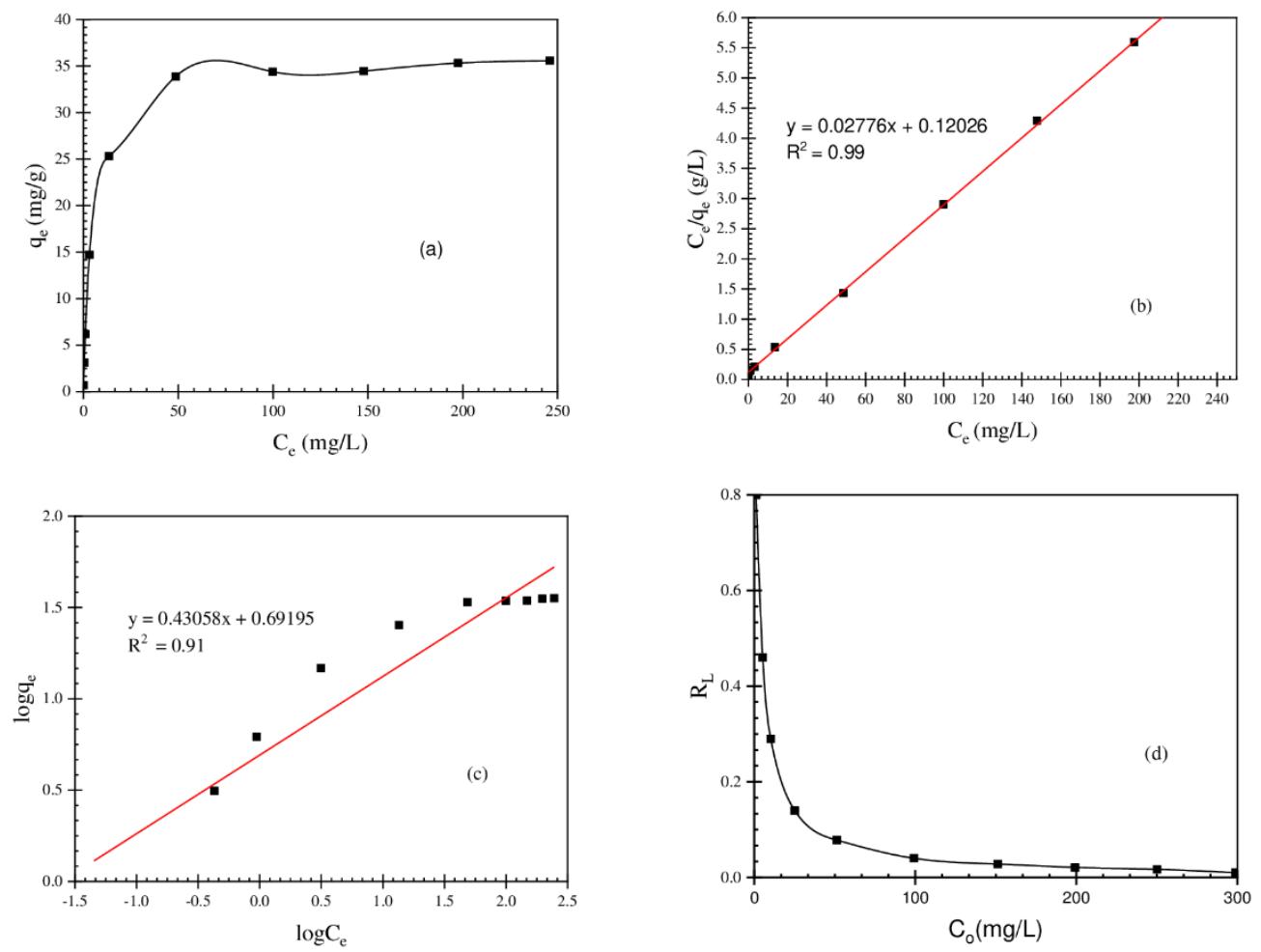

Figure 5. Adsorption isotherm studies onto Zr(IV)-SBP (a) Effect of initial concentration (b) Langmuir and (c) Freundlich isotherm model (d) variation of $\mathbf{R}_{\mathrm{L}}$ with initial concentration

Table 2. Isotherm parameters for adsorption of fluoride onto $\mathrm{Zr}(\mathrm{IV})$-SBP adsorbent

\begin{tabular}{lll}
\hline Models & Parameters & \\
\hline Langmuir & $\mathrm{q}_{\mathrm{m}}, \mathrm{cal} .(\mathrm{mg} / \mathrm{g})$ & 36.02 \\
& $\mathrm{~b}(\mathrm{~L} / \mathrm{g})$ & 0.23 \\
& $\mathrm{R}^{2}$ & 0.99 \\
& & \\
Freundlich & $\mathrm{K}_{\mathrm{F}}(\mathrm{mg} / \mathrm{g})$ & 4.91 \\
& $1 / \mathrm{n}$ & 0.43 \\
& $\mathrm{R}^{2}$ & 0.90 \\
\hline
\end{tabular}

Table 3. Comparison of fluoride adsorption capacity of investigated $\mathrm{Zr}$ (IV)-SBP with reported adsorbents

\begin{tabular}{|c|c|c|c|}
\hline Adsorbent & $\mathrm{pH}$ & $\mathrm{q}_{\mathrm{m}}(\mathrm{mg} / \mathrm{g})$ & References \\
\hline$\overline{\mathrm{Zr}(\mathrm{IV})-\mathrm{SBP}}$ & 2.94 & 36.02 & This study \\
\hline $\mathrm{CaCl}_{2}$ modified Crocus sativa leaves & 4.5 & 2.01 & (Dehghani et al., 2018) \\
\hline Engineered Biochar (EBC) & 7.0 & 0.985 & (De et al., 2018) \\
\hline Zr-modified tea waste & $3.0-10.0$ & 20.56 & (Mei et al., 2019) \\
\hline Rice husk biochar & 7.0 & 21.7 & (Goswami \& Kumar, 2018) \\
\hline Quaternary amine modified Turkish zeolite & 5.0 & 2.994 & (Aloulou et al., 2021) \\
\hline Cocos nucifera root & 7.0 & 2.037 & (George \& Tembhurkar, 2019) \\
\hline Coconut husk activated carbon & 5.0 & 6.5 & (Talat et al., 2018) \\
\hline Sandal wood leaf powder & $5.0-7.0$ & 5.88 & (Khound \& Bharali, 2018) \\
\hline
\end{tabular}

\section{Effect of adsorbent dose}

The adsorbent dose is one of the leading factors that determine the efficacy of adsorption for the examined adsorption system. The effect of adsorbent dose on the residual fluoride concentration was investigated and the result is presented in Fig. 6. The results show that the uptake of fluoride decreases rapidly in the initial stages with a gradual rise in adsorbent dose up to $2.0 \mathrm{~g} / \mathrm{L}$ then gradually decreased and reached less than $0.1 \mathrm{mg} / \mathrm{L}$ at 3.5 $\mathrm{g} / \mathrm{L}$. The $\mathrm{Zr}(\mathrm{IV})-\mathrm{SBP}$ dose of $2.0 \mathrm{~g} / \mathrm{L}$ can successfully lower the fluoride concentration below the maximum contaminant level of fluoride $(1.5 \mathrm{mg} / \mathrm{L})$ in drinking water as prescribed by WHO. The increase in adsorption with an increase in $\mathrm{Zr}(\mathrm{IV})-\mathrm{SBP}$ dosage can be attributed reasonably due to the increase of available active sites for the fluoride anion adsorption at a higher dose. 


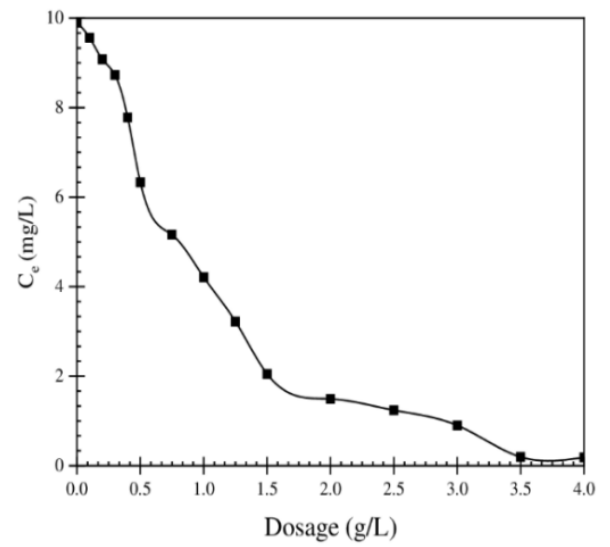

Figure 6. Effect of adsorbent dose in the adsorption of fluoride onto $\mathrm{Zr}(\mathrm{IV})$-SBP

\section{Effect of co-existing ions}

In actual fluoride polluted water, other commonly interfering anions such as chloride, sulphate, and nitrate have also existed. Therefore, the adsorption efficiency of fluoride in presence of co-existing ions such as chloride $(\mathrm{Cl})$, nitrate $\left(\mathrm{NO}_{3}{ }^{-}\right)$and sulphate $\left(\mathrm{SO}_{4}^{-}\right)$was tested using $\mathrm{Zr}(\mathrm{IV})-\mathrm{SBP}$ adsorbent. The experimental results are displayed in Fig. 7 which indicates that these ions marginally interfere with fluoride adsorption. The $\mathrm{Cl}^{-}$and $\mathrm{NO}_{3}$ - showed a mild effect at all concentration range while the elevated concentration of $\mathrm{SO}_{4}^{--}$showed the inhibitory effect during fluoride adsorption. The greater interference caused by $\mathrm{SO}_{4}^{--}$may be attributed due to greater charge density and high affinity of sulphate with loaded $\mathrm{Zr}(\mathrm{IV})$ in Zr(IV)-SBP (Paudyal et al., 2011; Aryal et al., 2021). Moreover, the existence of multiple co-existing ions $\left(\mathrm{Cl}^{-}\right.$ $+\mathrm{NO}_{3}{ }^{-}+\mathrm{SO}_{4}^{--}$) with fluoride solution in the adsorption system caused the greatest interference which is due to the synergistic effect of co-existing ions in the solution. The reduction in percentage adsorption of fluoride at an elevated concentration of co-existing ions is due to the competing effect of co-existing interfering ions against fluoride ions for the same adsorption sites during the fluoride adsorption process.

\section{Desorption studies}

The regeneration of the adsorbent lowers down the cost price of the adsorption process. Therefore, desorption studies are very important to regenerate the adsorbent and recovery of desorbed fluoride anion. The fluoride adsorption at higher $\mathrm{pH}$ was found to be unfavorable, so the desorption studies were conducted using a varying molar concentration of $\mathrm{NaOH}$ and the corresponding results are illustrated in Fig. 8. The results demonstrated that the desorption percentage increased from $61.19 \%$ to $95.6 \%$ on increasing the molar concentration of $\mathrm{NaOH}$ from 0.01 to 1 and reached the maximum value (98.5\%) by using $2 \mathrm{M} \mathrm{NaOH}$. Thus, $2 \mathrm{M} \mathrm{NaOH}$ solution was optimized for the effective desorption of adsorbed fluoride from fluoride adsorbed $\mathrm{Zr}(\mathrm{IV})$-SBP. It is inferred that the hydroxide ion that existed in the desorbing solution of $\mathrm{NaOH}$ undergoes ligand exchange reaction with fluoride ions thereby resulting in efficient desorption as shown in reaction $\mathbf{e}$.

$\equiv \mathrm{Zr}-\mathrm{F}$ (fluoride loaded $\mathrm{Zr}(\mathrm{IV})-\mathrm{SBP})+\mathrm{OH}^{-} \rightarrow \equiv \mathrm{Zr}-\mathrm{OH}$ (regenerated $\mathrm{Zr}(\mathrm{IV})-\mathrm{SBP})+\mathrm{F}^{-}$ 


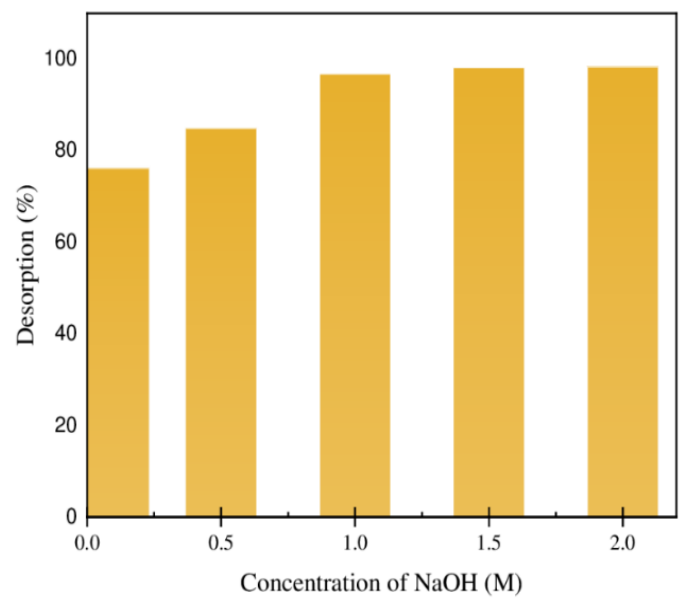

Figure 8. Desorption of fluoride from fluoride adsorbed $\mathrm{Zr}$ (IV)-SBP

\section{CONCLUSIONS}

An adsorbent, $\mathrm{Zr}$ (IV)-SBP was successfully synthesized by equilibrating banana peels waste with $\mathrm{Ca}(\mathrm{OH})_{2}$ followed by loading with $\mathrm{Zr}(\mathrm{IV})$ to develop anion exchange sites for fluoride ion removal. SEM, FTIR, and zeta potential measurement suggested the successful loading of $\mathrm{Zr}(\mathrm{IV})$ in the banana waste biopolymer. The adsorption capacity of $\mathrm{Zr}(\mathrm{IV})-\mathrm{SBP}$ was greatly influenced by the $\mathrm{pH}$ of the solution, equilibrium contact time, fluoride ion concentration, dose, and co-existing ions. The maximum fluoride adsorption capacity of $\mathrm{Zr}(\mathrm{IV})-\mathrm{SBP}$ evaluated from the Langmuir isotherm model was $36.02 \mathrm{mg} / \mathrm{g}$. The results were best obeyed with the Langmuir adsorption isotherm and pseudo second order kinetics. The interfering effects of $\mathrm{Cl}^{-}$and $\mathrm{NO}_{3}^{-}$was found to be insignificant while $\mathrm{SO}_{4}^{--}$exhibited notable effect in binary system. The interfering effect in multiple co-existing system is higher than binary system due to the synergistic effect of all the co-existing ions. Almost complete elution of adsorbed fluoride was achieved using a $2 \mathrm{M} \mathrm{NaOH}$ solution. The results disclosed that $\mathrm{Zr}(\mathrm{IV})-\mathrm{SBP}$ can be used as an efficient, environmentally friendly material to eliminate fluoride ion even at trace concentrations from fluoride polluted water.

\section{ACKNOWLEDGEMENTS}

Authors are thankful to Dr Bipeen Dahal, Jeonbuk National University, Jeonju, South Korea for SEM images, Dr Tista Prasai Joshi, Nepal Academy of Science and Technology, Khumaltar, Lalitpur, Nepal for zeta potential measurement. Additionally, to Mr Dipak Kumar Hitan, Laboratory section, Department of Customs, Ministry of Finance, Tripureshwor, Kathmandu for FTIR recordings.

\section{AUTHOR CONTRIBUTIONS}

RLA: conceptualization, investigation, writing original draft, and reviewing; BRP: methodology, software, reviewing; MRP: conceptualization, editing; HP: supervision, project administration, writing-reviewing, and editing; KNG: supervision, resources, conceptualization, writing-reviewing, and editing. All authors have read and agreed to the published version of the manuscript.

\section{CONFLICTS OF INTEREST}

The authors declare no conflict of interest pertinent to this work.

\section{DATA AVAILABILITY STATEMENT}

The data that support the findings of this study are available from the corresponding author, upon reasonable request.

\section{REFERENCES}

Abdulfatai, J., Saka, A.A., Afolabi, A.S., \& Micheal, O. (2013). Development of adsorbent from banana peel for wastewater treatment. Applied Mechanics and Materials, 248, 310-315. https://doi.org/10.4028/www.scientific

Aloulou, H., Ghorbel, A., Aloulou, W., Ben Amar, R., \& Khemakhem, S. (2021). Removal of fluoride ions (F-) from aqueous solutions using modified Turkish zeolite with quaternary ammonium. Environmental Technology, 42(9), 13531365. https://doi.org/10.1080/09593330.2019.1668863.

Appel, J. (1973). Freundlich's adsorption isotherm. Surface Science, 39(1), 237-244. https://doi.org/10.1016/0039-6028(73)901 05-2.

Aryal, R.L., Bhurtel, K.P., Poudel, B.R., Pokhrel, M.R., Paudyal, H., \& Ghimire, K.N. (2021). Sequestration of phosphate from water onto modified watermelon waste loaded with $\mathrm{Zr}(\mathrm{IV})$. Separation Science and Technology, 57(1), 70-82. https:// doi.org/10.1080/01496395.2021.1884878.

Aryal, R.L., Poudel, B.R., Gautam, S.K., Paudyal, H., Pokhrel, M.R., \& Ghimire, K.N. (2019). Removal of fluoride from aqueous solution using biomass -based adsorbents: A review. Journal of Nepal Chemical Society, 40, 44-51. https://doi.org/ht tps://doi.org:10.3126/jncs.v40i0.27281.

Bibi, S., Farooqi, A., Yasmin, A., Kamran, M.A., \& Niazi, N.K. (2017). Arsenic and fluoride removal by potato peel and rice husk (PPRH) ash in aqueous environments. International Journal of Phytoremediation, 19(11), 1029-1036. https://doi.org /10.1080/15226514.2017.1319329.

Biswas, G., Kumari, M., Adhikari, K., \& Dutta, S. (2017). 
Application of response surface methodology for optimization of biosorption of fluoride from groundwater using Shorea robusta flower petal. Applied Water Science, 7(8), 4673-4690. https://doi.org/10.1007/s13201-017-0630-5.

De, D., Santosha, S., Aniya, V., Sreeramoju, A., \& Satyavathi, B. (2018). Assessing the applicability of an agro-industrial waste to Engineered Bio-char as a dynamic adsorbent for Fluoride Sorption. Journal of Environmental Chemical Engineering, 6(2), 2998-3009. https://doi.org/10.1016/j.jece.2018.04.021.

Dehghani, M.H., Farhang, M., Alimohammadi, M., Afsharnia, M., \& Mckay, G. (2018). Adsorptive removal of fluoride from water by activated carbon derived from $\mathrm{CaCl}_{2}$ modified Crocus sativus leaves: equilibrium adsorption isotherms,optimization, and influence of anions. Chemical Engineering Communications, 205(7), 955-965. https://doi.org/ 10.1080/00986445.2018.1423969.

Djouadi Belkada, F., Kitous, O., Drouiche, N., Aoudj, S., Bouchelaghem, O., Abdi, N., Grib, H., \& Mameri, N. (2018). Electrodialysis for fluoride and nitrate removal from synthesized photovoltaic industry wastewater. Separation and Purification Technology, 204, 108-115. https://doi.org/10.1016 /j.seppur.2018.04.068.

Emaga, T.H., Robert, C., Ronkart, S.N., Wathelet, B., \& Paquot, M. (2008). Dietary fibre components and pectin chemical features of peels during ripening in banana and plantain varieties. Bioresource Technology, 99(10), 4346-4354.https://doi .org/10.1016/j.biortech.2007.08.030.

Gawkowska, D., Cieśla, J., Zdunek, A., \& Cybulska, J. (2019). Cross-linking of diluted alkali-soluble pectin from apple (Malus domestica fruit) in different acid-base conditions. Food Hydrocolloids, 92, 285-292. https://doi.org/10.1016/j.foodhy d.2019.02.010.

George, A.M., \& Tembhurkar, A.R. (2019). Analysis of equilibrium, kinetic, and thermodynamic parameters for biosorption of fluoride from water onto coconut (Cocos nucifera Linn.) root developed adsorbent. Chinese Journal of Chemical Engineering, 27(1), 92-99. https://doi.org/10.1016/j .cjche.2018.03.004.

Ghimire, K.N., \& Inoue, K. (2007). Optimization of saponification process for orange and apple wastes. Journal of Nepal Chemical Society, 22, 41-46. https://doi.org/10.3126/jn cs.v22i0.521.

Goswami, R., \& Kumar, M. (2018). Removal of fluoride from aqueous solution using nanoscale rice husk biochar. Groundwater for Sustainable Development, 7, 446-451. https://doi .org/10.1016/j.gsd.2017.12.010.

Grzegorzek, M., Majewska-Nowak, K., \& Ahmed, A.E. (2020). Removal of fluoride from multicomponent water solutions with the use of monovalent selective ion-exchange membranes. Science of the Total Environment, 722, 137681. https://doi.org/10.1016/j.scitotenv.2020.137681.

Jeyaseelan, A., Naushad, M., Ahamad, T., \& Viswanathan, N. (2021). Design and development of amine functionalized iron-based metal organic frameworks for selective fluoride removal from water environment. Journal of Environmental Chemical Engineering, 9(1), 104563. https://doi.org/10.1016/j .jece.2020.104563.

Khound, N.J., \& Bharali, R.K. (2018). Biosorption of fluoride from aqueous medium by Indian sandalwood (Santalum album) leaf powder. Journal of Environmental Chemical Engineering, 6(2), 1726-1735. https://doi.org/10.1016/j.jece.2 018.02.010.

Liu, Y., Fan, Q., Wang, S., Liu, Y., Zhou, A., \& Fan, L. (2016). Adsorptive removal of fluoride from aqueous solutions using
Al-humic acid-La aerogel composites. Chemical Engineering Journal, 306, 174-185. https://doi.org/10.1016/j.cej.2016.07 .036 .

Mahfoudhi, N., \& Boufi, S. (2020). Porous material from cellulose nanofibrils coated with aluminum hydroxyde as an effective adsorbent for fluoride. Journal of Environmental Chemical Engineering, 8(3), 103779. https://doi.org/10.1016/j .jece.2020.103779.

Mei, L., Peng, C., Qiao, H., Ke, F., Liang, J., Hou, R., Wan, X., \& Cai, H. (2019). Enhanced removal of fluoride by zirconium modified tea waste with extrusion treatment: kinetics and mechanism. RSC Advances, 9(57), 33345-33353. https://doi.org/10.1039/C9RA07155E.

Owusu-Agyeman, I., Reinwald, M., Jeihanipour, A., \& Schäfer, A.I. (2019). Removal of fluoride and natural organic matter removal from natural tropical brackish waters by nanofiltration/reverse osmosis with varying water chemistry. Chemosphere, 217, 47-58. https://doi.org/10.1016/j.chemosp here.2018.10.135.

Oyewo, O.A., Onyango, M.S., Wolkersdorfer, C. (2018). Lanthanides removal from mine water using banana peels nanosorbent. International Journal of Environmental Science and Technology, 15, 1265-1274. https://doi.org/10.1007/s13762017-1494-9.

Paudyal, H., Pangeni, B., Inoue, K., Kawakita, H., Ohto, K., Ghimire, K. N., \& Alam, S. (2013). Preparation of novel alginate based anion exchanger from Ulva japonica and its application for the removal of trace concentrations of fluoride from water. Bioresource Technology, 148, 221-227. https://doi.org/10.1016/j.biortech.2013.08.116.

Paudyal, H., Pangeni, B., Inoue, K., Kawakita, H., Ohto, K., Harada, H., \& Alam, S. (2011). Adsorptive removal of fluoride from aqueous solution using orange waste loaded with multi-valent metal ions. Journal of Hazardous Materials, 192(2), 676-682. https://doi.org/10.1016/j.jhazmat.2011.05 .070 .

Paudyal, H., Pangeni, B., Nath Ghimire, K., Inoue, K., Ohto, K., Kawakita, H., \& Alam, S. (2012). Adsorption behavior of orange waste gel for some rare earth ions and its application to the removal of fluoride from water. Chemical Engineering Journal, 195-196, 289-296. https://doi.org/10.1016/j.cej.201 2.04.061.

Siddique, A., Nayak, A.K., \& Singh, J. (2020). Synthesis of $\mathrm{FeCl}_{3^{-}}$ activated carbon derived from waste Citrus limetta peels for removal of fluoride: An eco-friendly approach for the treatment of groundwater and bio-waste collectively. Groundwater for Sustainable Development, 10, 100339. https:/ / doi .org/10.1016/j.gsd.2020.100339.

Solanki, Y.S., Agarwal, M., Maheshwari, K., Gupta, S., Shukla, P., \& Gupta, A.B. (2021). Removal of fluoride from water by using a coagulant (inorganic polymeric coagulant). Environmental Science and Pollution Research, 28(4), 3897-3905. https://doi.org/10.1007/s11356-020-09579-2.

Sposito, G. (1982). On the Use of the Langmuir Equation in the Interpretation of "Adsorption" Phenomena: II. The "TwoSurface" Langmuir Equation. Soil Science Society of America Journal, 46(6), 1147-1152. https://doi.org/10.2136/sssaj1982 $.03615995004600060006 x$.

Takmil, F., Esmaeili, H., Mousavi, S.M., \& Hashemi, S.A. (2020). Nano-magnetically modified activated carbon prepared by oak shell for treatment of wastewater containing fluoride ion. Advanced Powder Technology, 31(8), 3236-3245. https://doi.org /10.1016/j.apt.2020.06.015.

Talat, M., Mohan, S., Dixit, V., Singh, D.K., Hasan, S.H., \& 
Srivastava, O.N. (2018). Effective removal of fluoride from water by coconut husk activated carbon in fixed bed column: Experimental and breakthrough curves analysis. Groundwater for Sustainable Development, 7, 48-55.https://doi.org/10.1016/j .gsd.2018.03.001.

Tan, T.L., Krusnamurthy, P.A., Nakajima, H., \& Rashid, S.A. (2020). Adsorptive, kinetics and regeneration studies of fluoride removal from water using zirconium-based metal organic frameworks. RSC Advances, 10(32), 18740-18752. https://doi.org/10.1039/d0ra01268h.

Tang, Y., Guan, T., Gao, S.N., \& Wang, J. (2009). Fluoride adsorption onto activated alumina: modeling effect of $\mathrm{pH}$ and some competing ions. Colloids and Surfaces $A$ : Physicochemical Engineering Aspect, 337, 33-38. https://doi.org/ 10.1016/i.colsurfa.2008.11.027.

Tomar, V., Prasad, S., \& Kumar, D. (2014). Adsorptive removal of fluoride from aqueous media using Citrus limonum (lemon) leaf. Microchemical Journal, 112, 97-103. https://doi.org/10.10 16/j.microc.2013.09.010.

WHO. (2017). Guidelines for Drinking-water Quality: fourth edition to the first addendum, World Health Organization.

Xu, L., Chen, G., Peng, C., Qiao, H., Ke, F., Hou, R., Li, D., Cai, H., \& Wan, X. (2017). Adsorptive removal of fluoride from drinking water using porous starch loaded with common metal ions. Carbohydrate Polymers,160, 82-89. https://doi.org/ 10.1016/j.carbpol.2016.12.052.

Zirpe, M., Bagla, H., \& Thakur, J. (2020). Adsorptive removal of fluoride using polymer-modified ceria nanoparticles: determination of equilibrium, kinetic and thermodynamic parameters. Separation Science and Technology, 55(16), 29332947. https://doi.org/10.1080/01496395.2019.1660674. 